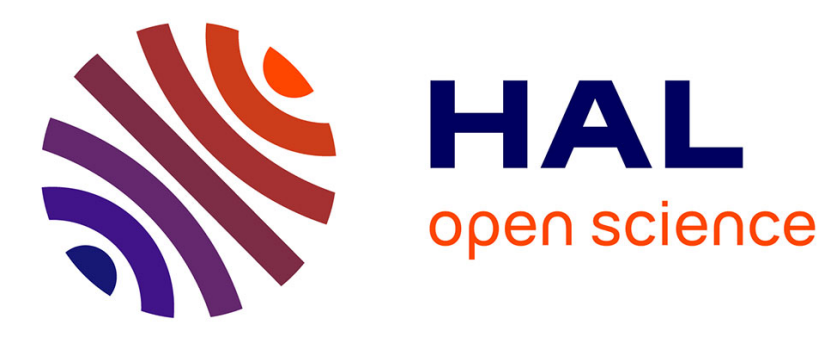

\title{
Genetic variability of berry size in grapevine (Vitis vinifera L.)
}

Cléa Houel, Marie-Laure Magniette, Stéphane D. Nicolas, Thierry Lacombe, Loic Le Cunff, Damien Franck, Laurent Torregrosa, Geneviève Conejero, Sandrine Lalet, Patrice This, et al.

\section{To cite this version:}

Cléa Houel, Marie-Laure Magniette, Stéphane D. Nicolas, Thierry Lacombe, Loic Le Cunff, et al.. Genetic variability of berry size in grapevine (Vitis vinifera L.). Australian Journal of Grape and Wine Research, 2013, 19 (2), pp.208-220. 10.1111/ajgw.12021 . hal-01223540

\section{HAL Id: hal-01223540 https://hal.science/hal-01223540}

Submitted on 19 Nov 2015

HAL is a multi-disciplinary open access archive for the deposit and dissemination of scientific research documents, whether they are published or not. The documents may come from teaching and research institutions in France or abroad, or from public or private research centers.
L'archive ouverte pluridisciplinaire HAL, est destinée au dépôt et à la diffusion de documents scientifiques de niveau recherche, publiés ou non, émanant des établissements d'enseignement et de recherche français ou étrangers, des laboratoires publics ou privés. 


\title{
Genetic variability of berry size in the grapevine (Vitis vinifera $\mathrm{L}$.)
}

\author{
C. HOUEL ${ }^{1,2}$, M.-L. MARTIN-MAGNIETTEE ${ }^{1,3}$, S.D. NICOLAS ${ }^{4,5}$, T. LACOMBE ${ }^{4,6}$, L. LE CUNFF LA $^{7}$ \\ D. FRANCK', L. TORREGROSA ${ }^{2}$, G. CONÉJÉRO ${ }^{8}$, S. LALET ${ }^{7}$, P. THIS $^{4}$ and A-F. ADAM-BLONDON' \\ ' UMRI I 65 URGV, INRA, 2 rue Gaston Crémieux, BP 5708, 91057 Evry, France \\ ${ }^{2}$ UMR 9995 AGAP, Montpellier SupAgro, 2 place Pierre Viala, 34060 Montpellier, France \\ ${ }^{3}$ Unité Mixte de Recherche Statistiques et Génomes, INRA, 7523I Paris, France \\ ${ }^{4}$ UMR 9995 AGAP, INRA, 2 place Pierre Viala, 34060 Montpellier, France \\ ${ }^{5}$ UMR0320 Unité Mixte de Recherches en Génétique Végétale, INRA, Ferme du Moulon, 91190 Gif sur Yvette, France \\ ${ }^{6}$ UEI057 Domaine de Vassal, INRA, route de Sète, 34340 Marseillan-Plage, France \\ ${ }^{7}$ Unité Mixte Technologique Géno-Vigne, INRA IFV SupAgro, IFV, Domaine de I’Espiguette, \\ 30240 Le Grau du Roi, France \\ ${ }^{8}$ Histology and Plant Cell Imaging Platform, CIRAD, avenue Agropolis, 34398 Montpellier, France \\ Correspondence authors: Dr Cléa Houel, email houel@supagro.inra.fr and \\ Dr Anne-Françoise Adam-Blondon, email adam@evry.inra.fr
}

\begin{abstract}
Background and Aims: Berry weight in the grapevine, as in the tomato, is variable, ranging from less than $1 \mathrm{~g}$ to $10 \mathrm{~g}$. In the tomato, berry weight depends on cell number and volume but also on carpel number. The aim of this work was to decipher the range of variation and to propose a role for subtraits possibly underlying berry size variation in a highly diverse collection of cultivated grapevines.

Methods and Results: Cell division before and after anthesis and cell expansion after anthesis appeared to be the major determinants of flesh weight variation between cultivars. Carpel number varied between cultivars, with two and three carpels per ovary. This trait, however, and also the seed weight did not clearly contribute to berry size variation, although a positive correlation was found between seed weight and number and berry weight at the intragenotypic level, in agreement with previous results.

Conclusions: This work deciphered the main anatomical factors underlying variation in berry size in Vitis vinifera; they involved both common fleshy fruits factors but also specific vine factors.

Significance of the Study: Further studies of the variation in berry size of the the grape will be assisted by the anatomical factors identified in this study.
\end{abstract}

Keyswords: berry weight, carpel number, cell number and volume, fruit size, Vitis vinifera $L$.

\section{Introduction}

Domestication of most crops has been accompanied by a dramatic increase in size of the harvested organs (Cong et al. 2008) that distinguishes domesticated taxa from their wild ancestors (Purugganan and Fuller 2009). Moreover, selection after domestication has resulted in a large phenotypic diversity in cultivars that can exceed the range of variation in their wild ancestors (Purugganan and Fuller 2009). For instance, cultivated tomato (Solanum lycopersicum) plants can produce fruits as much as 1000 times heavier than that of the wild tomato Solanum esculentum (Tanksley 2004). Similarly, wild grapevines (Vitis vinifera ssp. sativa) produce berries weighing less than $1 \mathrm{~g}$ while some cultivated grapevines ( $V$. vinifera subspecies sylvestris) produce berries that can weigh as much as $10 \mathrm{~g}$ (Boursiquot et al. 1995).

In fleshy fruits, such as the tomato or grapevine, the berries develop from an ovary after fertilisation. The ovary wall becomes the pericarp, which is composed of three distinct cell layers: the epicarp that corresponds to the skin; the mesocarp that corresponds to the flesh; and the endocarp that corresponds to the cell layers in contact with the seeds and that can be either fleshy in berries or lignified in stone fruits (Coombe 1976, Ollat et al. 2002). As in most other fleshy fruits, the growth of grape berries follows a double sigmoid curve, corresponding to three developmental stages (Coombe 1976). After flowering, during stage I, berry growth is due to cell mitotic division and cell expansion. Approximately 4-6 weeks post-anthesis, cell division ceases and only cell expansion subsists. At the end of stage I, all the tissues composing the seeds are formed. Stage II corresponds to a slow growth phase that ends with the veraison stage where the texture of the berry changes from hard to soft and the colour of the skin changes, which is easy to recognise for red cultivars. Finally, berry growth restarts in stage III but only through cell enlargement (Coombe 1976, Ojeda et al. 1999).

Berry growth in the tomato, as in the grapevine, is due to cell mitotic division and cell expansion by accumulation of water and secondary metabolites and, unlike in the grapevine, is due to endoreduplication (Tanksley 2004). Two main factors explain the variation in tomato fruit size (Tanksley 2004): first is 
the variation of cell volume and number; and second is the variation of carpel number (Tanksley 2004, Cheniclet et al. 2005, Cong et al. 2008, Guo and Simmons 2011, Muños et al. 2011, Wu et al. 2011). Thirty loci appear to be responsible for the majority of the variation (Tanksley 2004, Guo and Simmons 2011). A quantitative trait locus (QTL): fruit weight 2.2 was shown to control the variation of the ovarian cell number before anthesis and to explain 30\% of the difference in fruit size between large domesticated tomatoes and their small-fruited wild ancestor (Frary et al. 2000, Cong et al. 2002). The increase in carpel number in cultivated tomatoes has been shown to cause as much as a 50\% increase in fruit size (Cong et al. 2008, Muños et al. 2011). Two genes were involved in this varation: FASCIATED (Cong et al. 2008) and the tomato WUSCHEL homolg gene (corresponding to the locus: locule number $(L C)$; Muños et al. 2011). In the grapevine, few genetic studies of the determinism underlying variation in berry size have been undertaken. Moreover, in these studies the berry size trait was studied in progenies where the seedless trait was also segregating and both traits have strong interactions that make difficult the detection of a stable QTL specific for berry size (Doligez et al. 2002, Fanizza et al. 2005, Cabezas et al. 2006, Mejia et al. 2007, 2011). In addition, Fernandez et al. (2006a) showed that cell enlargement might explain the difference in berry size between three cultivars and their clonal variants that differ in berry size. In one of these clones, showing the fleshless berry extreme phenotype, the number of cells was also affected (Fernandez et al. 2006a, b). In the grapevine, unlike the tomato, a detailed comparative description of berry development in small versus large berry genotypes has not been made so far in a large sample of genotypes (Cheniclet et al. 2005).

The aim of this work was to identify the main anatomical factors underlying berry size variation in $V$. vinifera through a study of ovarian and berry components at several stages of development in a highly diverse collection of genotypes. This will allow: (i) a better comparison of the factors that influence variation in berry size in the grape and those important to the tomato, which will be useful for transferring knowledge from the model species for fleshy fruit to a perennial species; and (ii) identification of the best and easiest component(s) to be measured for fine phenotyping of berry size in future genetic studies.

\section{Materials and methods}

\section{Plant material}

The samples of berries and ovaries were harvested from 304 $V$. vinifera ssp. sativa genotypes listed in Table S1 and maintained in the French National Grapevine Germplasm Collection (INRA Domaine de Vassal, Montpellier, France; http://wwwl. montpellier.inra.fr/vassal/). We sampled 278 accessions from this collection following a two-step procedure that took into account the genetic structure within the collection and that minimised relatedness between accessions. The genetic structure of the whole collection was determined based on genotyping data of 2486 grapevine cultivated accessions with 20 short sequence repeats (SSR) (Laucou et al. 2011) and on using the STRUCTURE software (Pritchard Lab, University of Chicago, Chicago, IL, USA) (Pritchard et al. 2000). Three subpopulations are evidenced ( $\mathrm{K}=3$ from structure analysis; Figure S1), corresponding to the structure of grapevine diversity proposed by Negrul (1946), and consistent with the current knowledge about the history of grapevine cultivation (East vs West; see This et al. 2006) and the use of the cultivars (table vs wine). A panel of 93 cultivars was selected within each of these subpopulations among the least admixed accessions to minimise relatedness between accessions using both the max length subtree procedure implemented in the DARWIN software (CIRAD, Montpellier, France; http://darwin.cirad.fr/darwin) and known relatedness among grapevine cultivars (Lacombe et al. 2012) while retaining the most ancestral genitors of grapevine cultivars. The resulting panel contains 93 wine cultivars originating from Eastern Europe (WE), 92 wine cultivars originating from the Western Europe (WW) and 93 table cultivars (TE) based on germplasm from Eastern Europe, North Africa and the Eastern Mediterranean Basin. It captures $80 \%$ of the SSR genetic diversity of the French National Grapevine Germplasm Collection. Seventeen genotypes maximising the genetic diversity of cultivated $V$. vinifera sampled by Le Cunff et al. (2008) and described by Houel et al. (2010) were added to complete the sample. Eight other cultivated $V$. vinifera were added in order to improve the sampling of the phenotypic diversity for berry size in the cultivated grapevine.

\section{Berry and ovary phenotyping}

For each genotype, the average berry weight (30 berries) and diameter (ten berries) were measured from hard berries at veraison cut at the pedicel base (stage 81 from Biologische Bundesanstalt, Bundessorten amt und Chemische Industrie international scale; Lorenz et al. 1994) and from mature berries cut at the pedicel base (40 days after veraison; stage 89 from $\mathrm{BBCH}$ international scale). At the veraison stage, the berries have reached their final number of cells. The berries were randomly sampled within the bunches on at least two different bunches from two plants in 2008 (230 genotypes) and in 2009 for the genotypes which had no phenotyped berries the year before ( 23 genotypes) together with 18 control genotypes already phenotyped in 2008 that both represented the diversity of berry size observed in the sample of 2008 (range from $0.5 \mathrm{~g}$ to $4 \mathrm{~g}$ for berry weight at veraison) and the three subpopulations (six genotypes per subpopulation). The length (L) and the width (W) of the berries were measured from photographs using the ImageJ® version 1.43 software for Mac OS X (National Institutes of Health, Bethesda MD, USA; http://rsbweb.nih.gov/ij/download.html). The berry volume was estimated as an ellipsoid volume using the formula: $\mathrm{V}=4 / 3 . \pi . \mathrm{L} . \mathrm{W}^{2}$, and the berry shape was calculated as the ratio between the length and width of the berry. The number of seeds and the seed weight per berry were measured on ten berries at veraison (at this stage, the seeds are entirely formed (Ojeda et al. 1999) and easier to separate from the flesh than at ripeness). The flesh weight at the ripeness and veraison stages was estimated by subtracting the average seed weight from the average berry weight.

For a representative sample of 26 genotypes (corresponding to the 18 genotypes already used as controls with eight other genotypes without seedless cultivars, maximising together the diversity of berry size in the whole sample (range from $0.4 \mathrm{~g}$ to $4 \mathrm{~g}$ for berry weight at veraison) and well spread into the three subpopulations; Table S1), the berry weight, the seed weight and number were also measured individually from ten berries at ripeness, to study the intragenotypic correlation between traits.

For each genotype, the length and width of ovaries were measured from ten closed flowers (entirely formed but not fertilised). The flowers were sampled on at least two inflorescences showing a few open flowers (stage 61-62 from the BBCH international scale) from two plants. The ovary volume and shape were determined using the same method as for berries. The ovaries were cut widthwise in two pieces in order to count the number of carpels under a binocular. 


\section{3 berries per genotype}

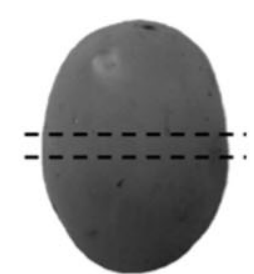

3 slides per berry

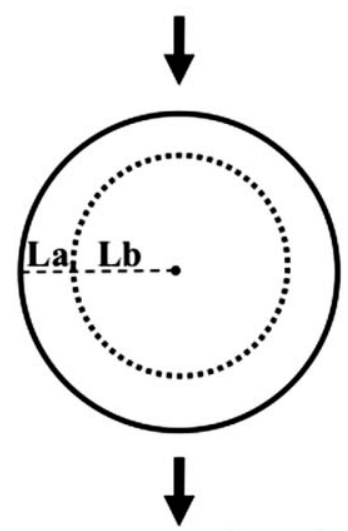

La: outer mesocarp length Lb: inner mesocarp length

a: outer mesocarp; b: inner mesocarp; c: epicarp; d: vascular bundle; e: endocarp

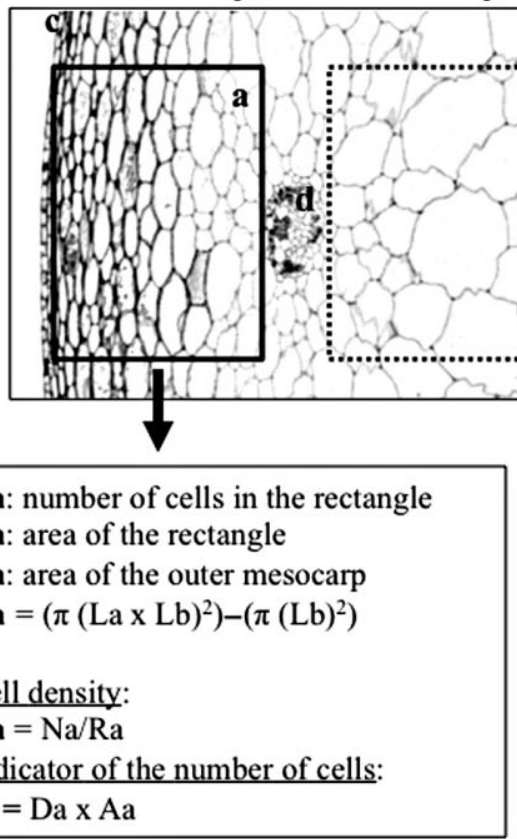

$\mathbf{N b}$ : number of cells in the rectangle
$\mathbf{R b}:$ area of the rectangle
$\mathbf{A b}:$ area of the inner mesocarp
$\mathbf{A b}=\pi(\mathrm{Lb})^{2}$
Cell density:
$\mathbf{D b}=\mathrm{Nb} / \mathrm{Rb}$
Indicator of the number of cells:
$\mathbf{I b}=\mathrm{Db} \times \mathrm{Ab}$

Figure 1. Method for the calculation of the indicators of the number and the volume of cells in the mesocarp of berries at veraison. la and $\mathrm{lb}$ are, respectively, the indicators of the number of cells in the outer and inner mesocarp. Da and $\mathrm{Db}$ are the indicators of the cell volume in the outer and inner mesocarp, respectively. The black bar scale corresponds to $0.01 \mathrm{~cm}$.

\section{Berry and ovary preparation for microscopy}

Three closed flowers and three berries at veraison per genotype, from the representative sample of 26 genotypes from the three subpopulations (Table S1), were randomly chosen among the previous 30 collected berries, vacuum infiltrated three times for $10 \mathrm{~min}$ in a cold solution of fixative (sodium phosphate buffer $0.1 \mathrm{M} \mathrm{pH} 7.2,2 \%$ paraformaldehyde, $1 \%$ glutaraldehyde and $1 \%$ caffeine) and maintained in a fresh fixative solution for at least $48 \mathrm{~h}$ at $4^{\circ} \mathrm{C}$. For each berry, the pieces with the larger diameter of the berry (Figure 1) were futher prepared; they were washed in a solution of $70 \%$ ethanol before removing the seeds and dehydrated through a series of incubations in ethanol: $70 \%$ ethanol for $1 \mathrm{~h}, 95 \%$ ethanol for $\mathrm{l} \mathrm{h}$ and finally, $100 \%$ ethanol for $24 \mathrm{~h}$ at $4^{\circ} \mathrm{C}$. The dehydrated samples were incubated in Technovit 7100 cold-curing resin for soft tissues (Kulzer, Labonord SAS, Templemars, France) for at least 2 weeks shaking at $4^{\circ} \mathrm{C}$. After addition of $1 \%$ methyl methacrylate (hardener solution), the resin was allowed to polymerise at $37^{\circ} \mathrm{C}$ for $24 \mathrm{~h}$ in a dry atmosphere. After inclusion, the samples were cut into $3 \mu \mathrm{m}$ sections using a Leica RM2255 (Leica Microsystèmes SAS, Nanterre, France) microtome, stained in a solution of $0.1 \%$ Alcian blue $8 \mathrm{GX}$ and $0.01 \mathrm{M}$ sodium citrate/0.01 M hydrogen chloride $(\mathrm{HCl})$ buffer $\mathrm{pH} 3.5$ for $24 \mathrm{~h}$ in order to allow visualising of the cell membranes, washed twice in sodium citrate/HCl buffer pH 3.5 and finally mounted on slides with Isomount medium (Labonord SAS).

\section{Histological studies of berries and ovaries}

The berry and ovary sections were observed under a microscope (DM 4500, Leica). Three objectives were used: $\times 5$ for measuring berry outer and inner mesocarp length and for counting the berry cell number; $\times 10$ for measuring ovary outer and inner mesocarp length; and $\times 20$ for counting the number of ovarian cells. Images were taken on each slide with a camera (Micropublisher version 3.3 RTV; Q-Imaging company, Surrey, Canada) coupled to the microscope and driven by the Volocity image analysis software version 5.4.1 (PerkinElmer Company, Waltham, MA, USA) for Mac OS (http://www. 
cellularimaging.com/products/volocity/). The three best slices for each three ovaries and berries per genotype were chosen (see Figure 1 for berries), and if necessary, the berry slices were reconstructed from images by photomerge using the software Photoshop version CS3 (Adobe, San Jose, CA, USA). The outer and inner mesocarp cell density was estimated as the number of cells present in a defined area chosen in order to capture the maximum of cell size variability of the corresponding mesocarp at the largest diameter of the berry (Figure 1), using the software ImageJ (National Institutes of Health, Bethesda, MD, USA). The cell density was used as an indicator of the cell volume because it is inversely correlated with the cell volume. The outer and inner mesocarp cell numbers were estimated using the cell density multiplied by the area of the corresponding mesocarp, and represented the number of cells on a slice of ovary or berry (Figure 1).

\section{Heritability}

The broad-sense heritability $\left(\mathrm{H}^{2}\right)$ was estimated for the berry weight at ripeness of 155 individuals according to Knapp et al. (1985) using our 2008 data and 2000 data extracted from the database associated with the French National Grapevine Germplasm Collection (Domaine de Vassal database; http://bioweb. ensam.inra.fr/collections_vigne/) considered as an independent repetition. $\mathrm{H}^{2}$ was also estimated for the berry weight of the 18 control individuals at veraison using the data collected in 2008 and 2009 in the present study.

\section{Statistical analysis}

All variables were log-transformed in order to better fit a Gaussian distribution. Statistical analyses were performed using the $\mathrm{R}$ software version 2.10.1 (The R Foundation for Statistical Computing, Vienna, Austria; http://www.r-project.org/). Linear regression and Pearson correlation value $(\mathrm{R})$ were estimated between each pair of variables. A Bonferroni correction was applied to control the familywise error rate at level 0.05 .

\section{Ward method clustering}

Data were clustered using the Ward method, which is an agglomerative clustering method. The similarity distance is the Euclidean distance, and the clustering criterion is based on the error sum of squares (E), which is defined as the sum of the squared distances of individuals from the centre of gravity of the bunch to which they have been assigned. Initially, E is zero because every individual is in a bunch of its own. At each stage, the link created is the one that makes the least increase to E.

\section{Results}

Distribution of the traits in the whole sample of cultivated genotypes and analysis in relation to berry size

Two hundred and fifty-four out of the 303 cultivated genotypes (Table S1) could be phenotyped for ovarian and/or berry traits during the two years. The missing data for $17 \%$ of all the genotypes were due mainly to millerandage (shot berries because of incomplete pollination and development of the grape bunch), rabbits or bird invasions, and in a few cases, due to too young plants not producing enough flowers and berries. All the parameters that were measured on ovaries just before anthesis, on berries at veraison (end of the stage where cell division and some cell extension occurs; Ojeda et al. 1999) and at ripeness (stage where only cell extension was observed by Ojeda et al. 1999) are summarised in Table 1. Labour-intensive histological parameters were measured only on a representative sample of
26 genotypes from the three subpopulations while the other parameters were measured on the panel of 254 cultivated grapevines (Table S1).

The berry flesh weight as well as the berry volume at ripeness varied, respectively, by a ten- and 23 -fold factor (Table 1), from $0.98 \mathrm{~g}$ and $0.5 \mathrm{~cm}^{3}$ (cv. Domina; Figure 2a) to $10.14 \mathrm{~g}$ and $11.5 \mathrm{~cm}^{3}$ (for cv. Barlinka; Figure 2a). The berry flesh weight at veraison varied exactly in the same range as that at ripeness whereas the range of berry volume variation was $50 \%$ smaller at veraison than at ripeness (Table 1 ). The volume of the ovary just before anthesis also varied greatly between the genotypes, with an 11 -fold difference between the smallest $\left(0.002 \mathrm{~cm}^{3}\right.$ for $\mathrm{cv}$. Ramisco; Figure 2b) and the largest $\left(0.022 \mathrm{~cm}^{3}\right.$ for $\mathrm{cv}$. Kozouzioum; Figure 2b; Table 1). The number of carpels per ovary varied between two and three within and between the genotypes (Table 1, Figure 2c), with $29 \%$ of the genotypes showing flowers with three carpels. As already mentioned by Ollat et al. (2002), the average seed number per berry in seeded cultivars was 1.9 (Table 1) with a nearly four-fold variation among the genotypes. The seed weight showed also a larger range of variation from $0.03 \mathrm{~g}$ to $0.22 \mathrm{~g}$ in seeded cultivars.

A strong correlation $(\mathrm{R}=0.86)$ was observed between the berry flesh weight at veraison and at ripeness. This showed that most of the events accounting for variation in berry size between genotypes were determined before veraison. Moreover, at ripeness, the berry flesh weight and the berry volume were highly correlated traits $(\mathrm{R}=0.91)$. Finally, there were more data missing at the ripeness stage because of pathogen attacks or birds feeding than at earlier stages of development. Therefore, the results obtained at veraison were preferentially used in the analysis, and when the results at ripeness were to be considered, only the berry flesh weight was analysed. Finally, the broad-sense heritability calculated for the berry weight at veraison and ripeness were 0.96 and 0.93 , respectively, between the 2008 and 2009 data (18 genotypes used as control) and between 2008 and Domaine de Vassal database data (155 genotypes). These results showed that berry weight was strongly heritable. Moreover, there was a strong correlation between the average berry flesh weight at veraison collected in 2008 and 2009 ( $\mathrm{R}=0.94$; Figure S2) and between 2008 and Domaine de Vassal data $(\mathrm{R}=0.91$; Figure $\mathrm{S} 2)$. All these results allowed us to merge the 2008 and 2009 data measured at veraison.

There was no significant intergenotypic correlation between the seed number or the seed weight per berry and the berry flesh weight at veraison or ripeness. Indeed, genotypes with a similar average seed number per berry showed different berry flesh weight: for example, the average berry flesh weight at ripeness of cv. Courbu and cv. Assoued Kere diverged from $1.20 \mathrm{~g}$ to $3.36 \mathrm{~g}$, respectively, with an average of 3.1 seeds per berry weighing $0.2 \mathrm{~g}$. The genotypes, however, with berries weighing more than $2 \mathrm{~g}$ at veraison ( $4 \mathrm{~g}$ or more at ripeness) always showed a seed weight per berry greater or equal to $0.1 \mathrm{~g}$ (data not shown). If the intragenotypic variation was considered using individual data from ten berries per genotype on the representative sample of 26 genotypes (Table S1), a significant correlation between variation in berry flesh weight and seed weight or the seed number variation per berry was observed (Table 2).

The number of carpels was not significantly correlated with the average ovary width and volume or with the average berry flesh weight. As for seed weight, a threshold effect was observed, with the genotypes having large berries (more than $2 \mathrm{~g}$ at veraison) always having large ovaries (upper or equal to $0.1 \mathrm{~cm}$ wide; data not shown). 


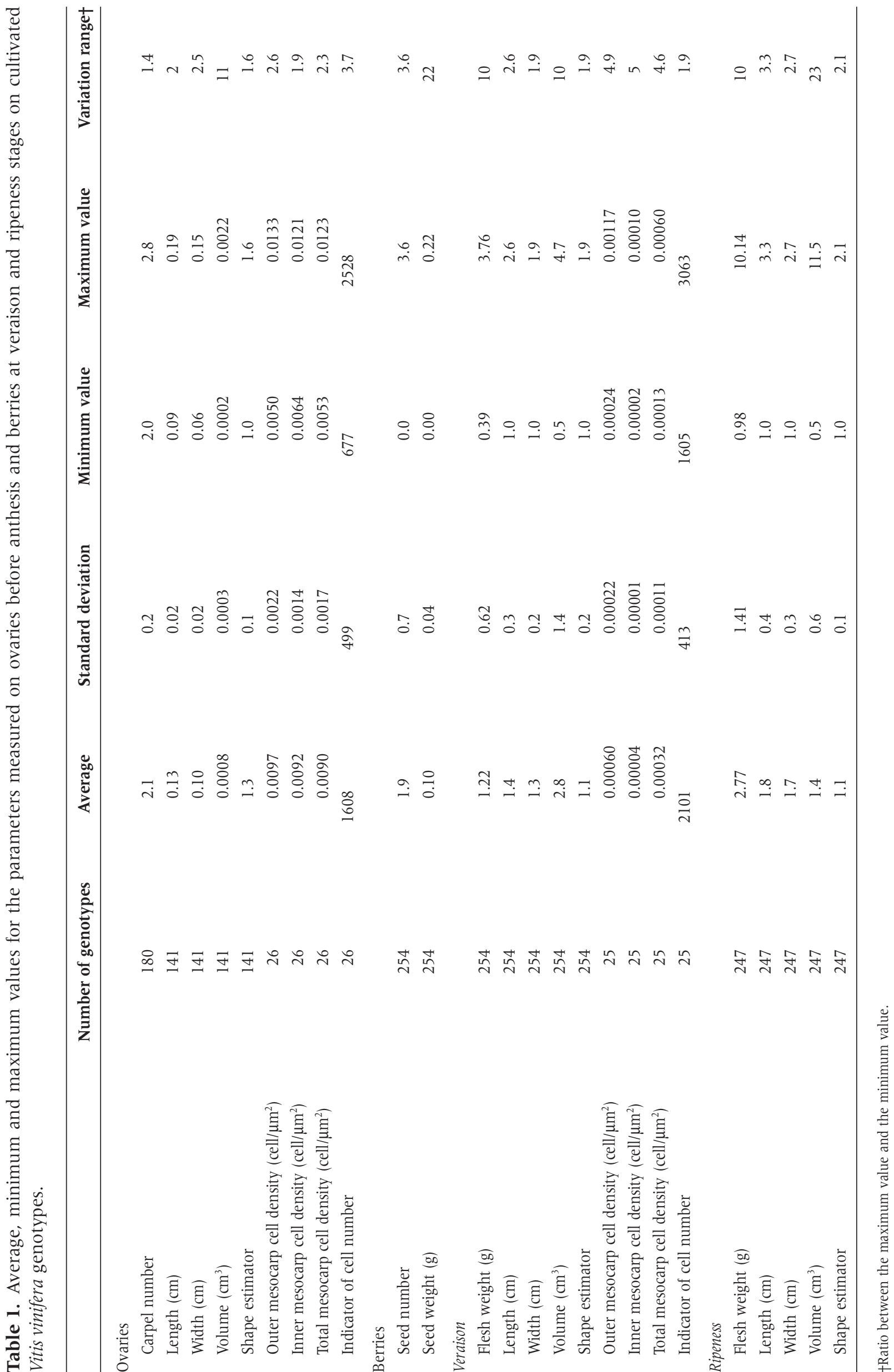




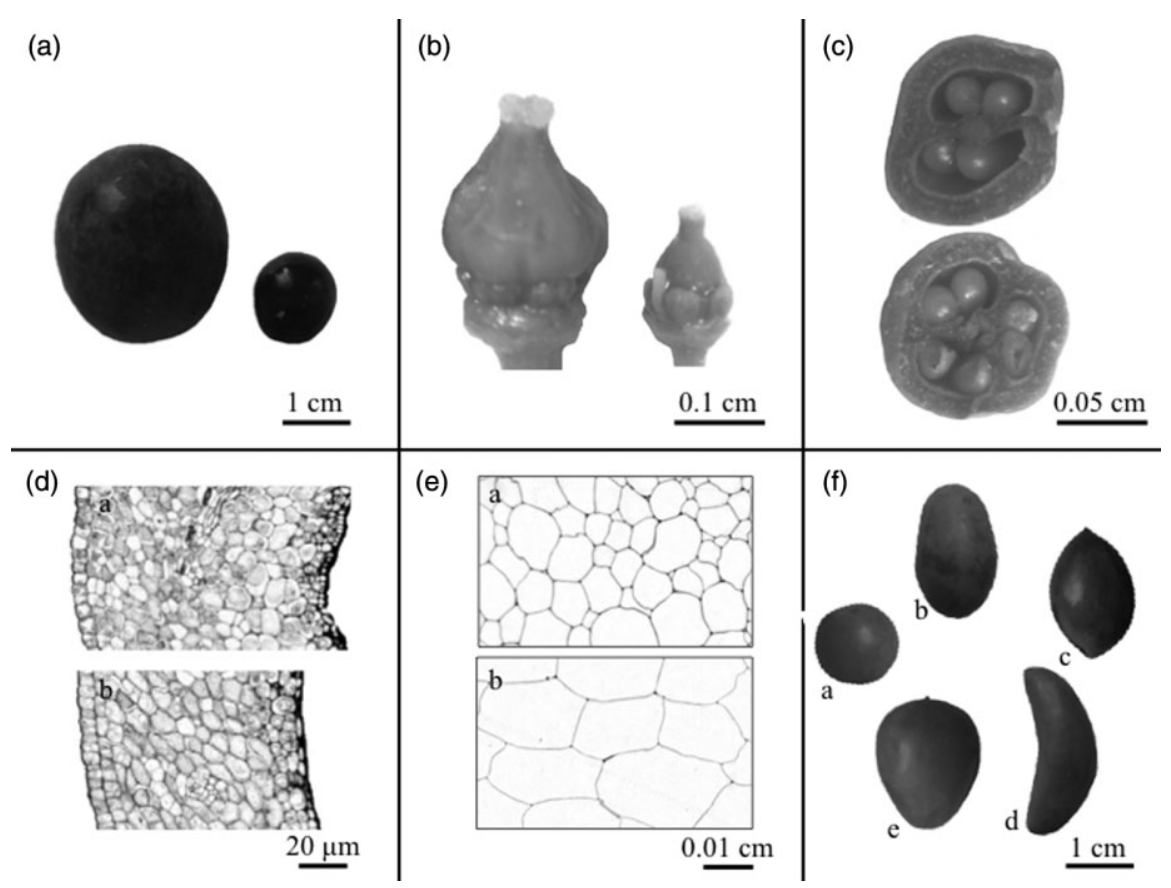

Figure 2. Variation of ovarian and berry traits in cultivated grapevine. (a) The largest and the smallest berries at ripeness, respectively, CV. Barlinka (left) and cv. Domina (right). (b) The largest and the smallest ovaries at anthesis, respectively, cv. Kozouzioum (left) and cv. Ramisco (right). (c) The range of carpel number variation in flowers from cultivated grapevine. (d) Transversal sections of ovaries at anthesis from (a) cv. Dabouki from Group D with large berries and (b) from cv. Fer from Group A with small berries, highlighting the difference in cell number. (e) Transversal sections of berries at veraison showing the difference in cell volume between (a) Cv. Fer and (b) cv. Dabouki. (f) Examples of of fruit shape variation at veraison: (a) cv. Moscato di Terracina from Group B, (b) cv. Aïn Kelba from Group B, (c) cv. Teta de Vaca from Group C, (d) cv. Coarna Alba from Group B, and (e) cv. Emerald from Group C.

Finally, the cell number and volume were measured in ovaries and in berries at veraison. Indeed, the berries have their final number of cells at veraison (Ojeda et al. 1999), and the final berry size was shown to be mainly determined before this stage in the present study. These traits were variable between the genotypes (Table 1; Figure 2d,e), respectively, with a factor of 3.7, 2.3, 1.9 and 4.6. There was not a significant correlation, however, between the variation in berry flesh weight and these ovarian and berry traits (data not shown).

\section{Clustering of the genotypes to reveal mechanism of berry size variation in grapevine}

The distribution of berry flesh weight in each of the three subpopulations was not superimposed at veraison or at ripeness (Figure 3). The mean berry flesh weight was significantly different between the three subpopulations ( $t$-test between all pairs of subpopulations $P$-value $<0.05$; data not shown). Different mechanisms involved in berry size variation that would have been selected independently in each of these subpopulations could explain these observations. In order to test this hypothesis, the correlation between the different parameters was calculated within the three subpopulations. No correlation was found between any of the different subtraits (ovary volume, carpel number, ovary cell number and volume, berry flesh cell number and volume, and seed number and weight) and berry flesh weight variation in any of the three subpopulations (data not shown). These results would indicate that the selection for berry size in the grapevine is independent of the evolutionary forces that shaped the cultivated $V$. vinifera germplasm into three subpopulations.

The Ward's method where genotypes were clustered using several phenotypic data (berry flesh weight, berry length and berry width at veraison together) was used in order to group the genotypes according to their berry weight and volume and without any knowledge of their origin or genetic structure. The dendrogram obtained after clustering is shown in Figure 4. The distribution into four groups (A, B, C, D) was adopted as it allowed the best balance in terms of numbers of individuals in each class (Figure 4), and a significantly different berry flesh weight at veraison between them (Table 3). There was, however, still an asymmetric distribution of the genotypes between groups, with Groups A and B containing the majority of the genotypes (respectively, 32\% and 50\%) whereas Groups $\mathrm{C}$ and D represented together $18 \%$ of all the genotypes (Table 4). Group A, which contained the genotypes with the smallest berries, contained mainly genotypes from the subpopulations WW $(64 \%)$ and WE $(28 \%)$ used for the wine industry, whereas Group D, containing grapes with the largest berries, contained only genotypes from the subpopulation TE $(100 \%)$ used as table grapes. Groups B and C contained a mix of the three subpopulations, with a proportion of TE individuals higher in Group C than in Group B. The sample distribution reflects the representation of European wine cultivars in the French National Grapevine Germplasm Collection, which has a majority of genotypes producing small to medium berries (Table 4; Cordonnier 1976, Le Cunff et al. 2008). The comparison of the distribution of the genotypes in the three subpopulations with their distribution in the four bunches based on berry size parameters showed that these two groupings are not independent (chi-squared contingency table test $P$-value $<0.05$; data not shown). This unbalanced distribution of the genotypes according to their berry size in the French National Grapevine Germplasm Collection was found again in the sample of 26 genotypes used for ovarian and berry cell phenotyping, these 26 genotypes having been chosen at the beginning of the study, in absence of in depth phenotypic 
Table 2. Intragenotypic correlation between berry flesh weight at ripeness and the seed number or the seed weight per berry on the sample of 26 cultivated Vitis vinifera genotypes.

\begin{tabular}{|c|c|c|c|}
\hline \multirow[t]{2}{*}{ Cultivar name } & \multirow[t]{2}{*}{ Accession number } & \multicolumn{2}{|c|}{ Pearson correlation } \\
\hline & & $\begin{array}{l}\text { Seed number/ } \\
\text { berry flesh weight }\end{array}$ & $\begin{array}{c}\text { Seed weight/ } \\
\text { berry flesh weight }\end{array}$ \\
\hline Baresana $=$ Korithi aspro & 1247Mtpl & 0.71 & $0.85^{*}$ \\
\hline Primitivo & 1277Mtp6 & $0.96^{*}$ & $0.97^{*}$ \\
\hline Ohanes & 1365Mtpl & $0.85^{*}$ & $0.84^{*}$ \\
\hline Alvarelhão & 1481Mtpl & $0.80^{*}$ & $0.83^{*}$ \\
\hline Carcajolo & 1531Mtpl & $0.73 *$ & $0.67^{*}$ \\
\hline Berbecel & 1573Mtpl & 0.70 & $0.76^{*}$ \\
\hline Kövidinka & 1578Mtpl & $0.85^{*}$ & $0.91^{*}$ \\
\hline Mondeuse & 16lMtpl & $0.85^{*}$ & $0.75^{*}$ \\
\hline Chaouch blanc & 1673Mtpl & 0.37 & $0.75^{*}$ \\
\hline Verdeca = Lagorthi & 2287Mtpl & $0.85^{*}$ & $0.87^{*}$ \\
\hline Roussaïtis & 2312Mtpl & 0.70 & $0.78^{*}$ \\
\hline Alexandroouli & 2500Mtpl & $0.72 *$ & $0.79 *$ \\
\hline Savagnin blanc & 257Mtpl & 0.56 & 0.71 \\
\hline Fer & 353Mtpl & $0.77 *$ & $0.87^{*}$ \\
\hline Courbu & 413Mtpl & $0.87^{*}$ & $0.89 *$ \\
\hline Razachie rosie & 433Mtpl & $0.83^{*}$ & $0.93 *$ \\
\hline Mauzac & 443Mtpl & $0.80^{*}$ & 0.61 \\
\hline Chasselas & 585Mtpl & 0.31 & 0.40 \\
\hline Olivette Blanche & 667Mtpl & 0.41 & 0.61 \\
\hline Nehelescol & 727Mtpl & $0.86^{*}$ & $0.84^{*}$ \\
\hline Dabouki† & 735Mtpl & - & - \\
\hline Heptakilo & 743Mtpl & $0.79 *$ & $0.87^{*}$ \\
\hline Coarna alba & 749Mtpl & $0.77^{*}$ & $0.79^{*}$ \\
\hline Ugni blanc & 74Mtpl & 0.63 & $0.92 *$ \\
\hline Calitor & 77Mtpl & 0.40 & $0.79 *$ \\
\hline Ahmar Derani & 848Mtpl & $0.72^{*}$ & $0.80^{*}$ \\
\hline
\end{tabular}

*Significant correlation with a Bonferonni correction at 0.05 (remark: in all the cases where no correlation was found, there was only two classes of seed weight or seed number). †Missing data because of genotype not producing enough berries.

analysis, to be representative of the three genotypic subpopulations (Table 3).

\section{Are there different mechanisms underlying berry size variation in the grapevine?}

All the parameters measured on berries and ovaries were analysed within and between genotypes from Groups A, B, C and D (Table 3). Significant differences between some to all groups were found for all the parameters except ovary cell volume, ovary shape estimator ( $t$-test $P$-value $<0.05$; data not shown), carpel number and seed number (generalised linear model $P$-value $<0.05$; data not shown). The volume of the ovary differed significantly between groups, with berries on average twofold larger in Group D than that in Group A (Table 3; Figure $2 \mathrm{~b}$ ). This difference in ovary volume was due mainly to a variation in ovary width for Group D, whereas for Group C, both ovary width and length participated (Table 3). Of the cellrelated parameters measured on ovaries, the cell volume estimated through the mesocarp cell density was not significantly different among the four groups, whereas the cell number was significantly different between Group A and Groups B and D (Table 3; Figures 2d, 5a). Although the carpel number did not appear to be directly involved in the variation of ovary volume or berry volume (Table 3), the number of genotypes which possessed ovaries with three carpels was higher in groups with genotypes producing the largest berries than in the others $(67 \%$ and $63 \%$, respectively, for Groups C and D; Table 3).

As expected, the seed number did not vary among groups whereas the seed weight was significantly different between Groups A and D (Table 3). Groups C and D had significantly larger berry flesh cells than that of Groups A and B (Figures 2e, $5 \mathrm{~b}$ ) in both the outer and inner mesocarp, and this differentiation clearly started after anthesis as shown both by the significant difference between the two development stages in cell density and in their expansion rate (Table 3 ). In addition, the number of berry flesh cells was still significantly lower in Group A than in Group D (Table 3; Figure 5c). In this case, however, the cell division rate in the mesocarp between the anthesis and the veraison stages is not significantly different between the four groups (Table 3). The ovary shape estimator did not differ significantly between groups (Table 3) and was not correlated to the final berry shape. In contrast, the berry shape estimator at veraison differed significantly between the four groups and was highly correlated to the berry shape at ripeness (Figure 2f). 

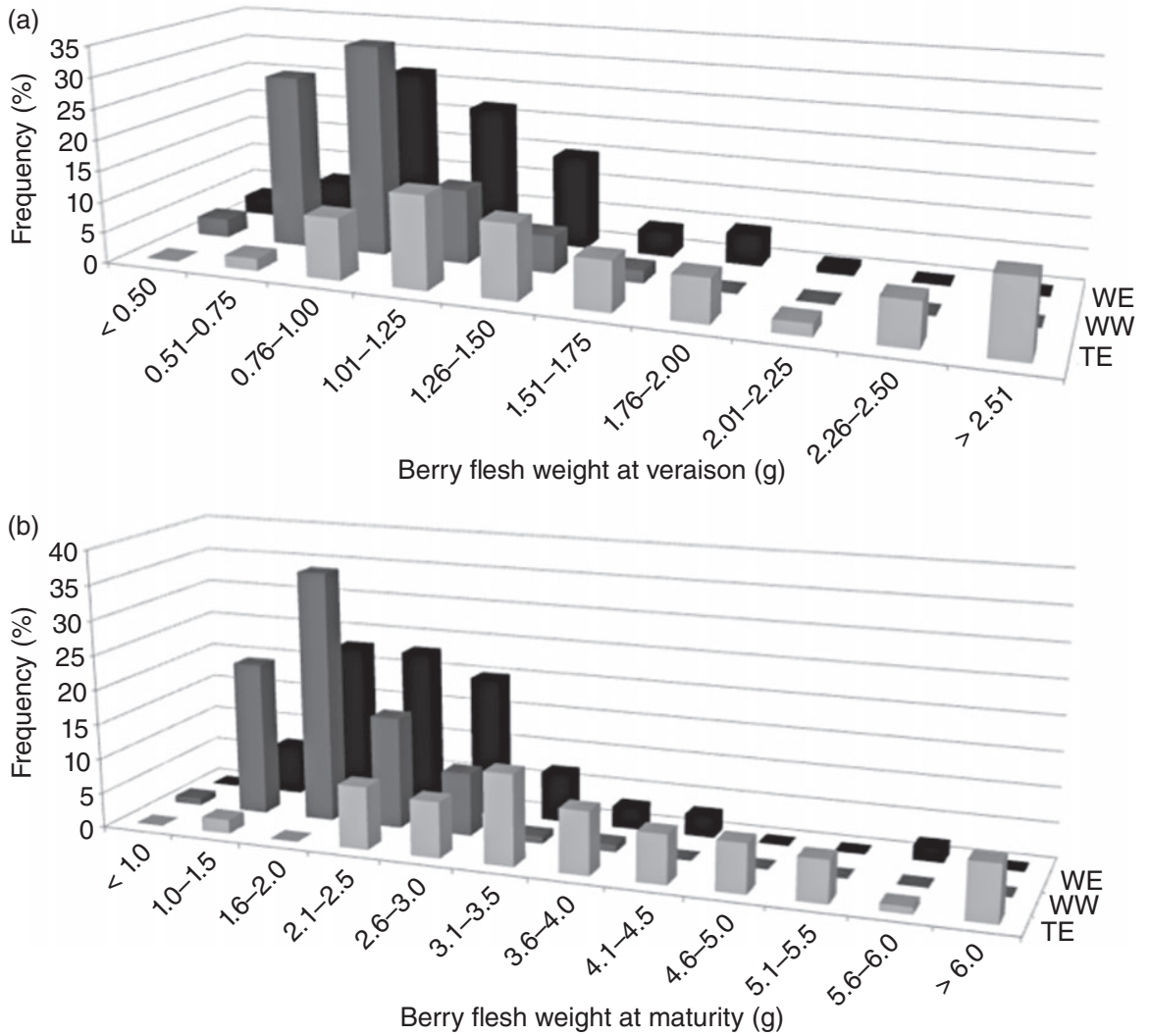

Figure 3. (a) Distribution of the berry flesh weight at veraison and (b) at ripeness in the three subpopulations. Table grape cultivars originating from Eastern Europe (TE) are in grey, wine grape cultivars originating from the Western Europe (WW) are in dark grey and wine grape cultivars originating from Eastern Europe (WE) are in black.

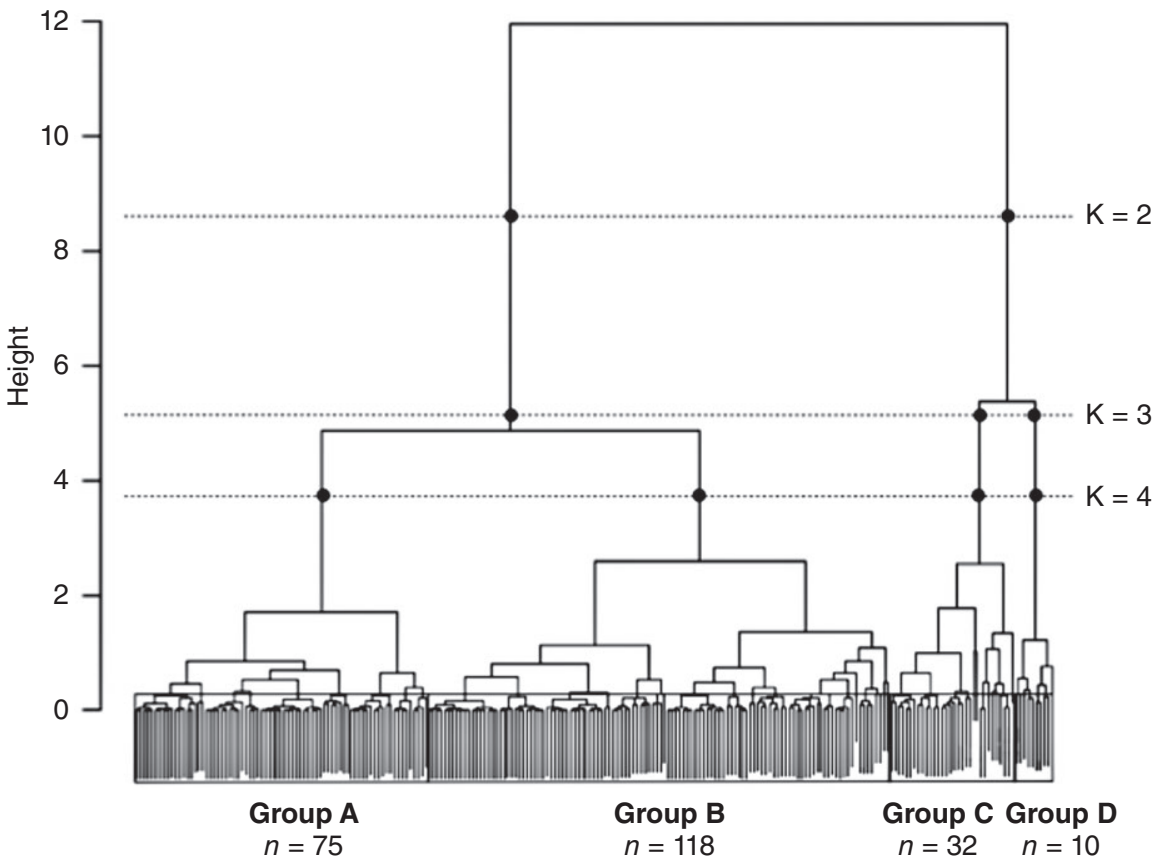

Figure 4. Clustering using the Ward method of cultivated Vitis vinifera genotypes based on berry flesh weight, berry length and berry width at veraison. $\mathrm{K}$ is the number of groups. The number of genotypes ( $n$ ) per Group for $K=4$ is indicated for each of Groups A, B, C, D (from the smallest to the largest berries).

Interestingly, the genotypes producing non-spherical berries were more frequent in groups with large berries $(45 \%$ and $80 \%$ of the genotypes for Groups C and D, respectively; Table 3). In addition, all groups, except Group A, comprised several genotypes producing berries with shapes different from round or ellipsoid (Figure 2f). For four of the parameters with a normal distribution, for which data were collected for three to ten individual berries in 26 individuals (berry weight, seed weight, berry cell density, ovary cell density), an analysis of variance, taking into account the intragenotypic variation (Table S2), confirmed the results presented earlier (Table S3).
To summarise, the variation in berry size appears to originate from variation in both ovary and berry traits (Table 3). In Group A, which contained the genotypes producing the smallest berries, berry size might be explained both by fewer ovarian cells and probably a cell growth limitation after anthesis, resulting in berries at veraison with fewer and smaller cells. Group B was characterised by a greater number of cells in the ovaries, which was more or less maintained during berry development, depending on the genotypes. The size of the berry cells, however, was not significantly different from those of Group A at veraison. The number of cells at anthesis appeared, therefore, 


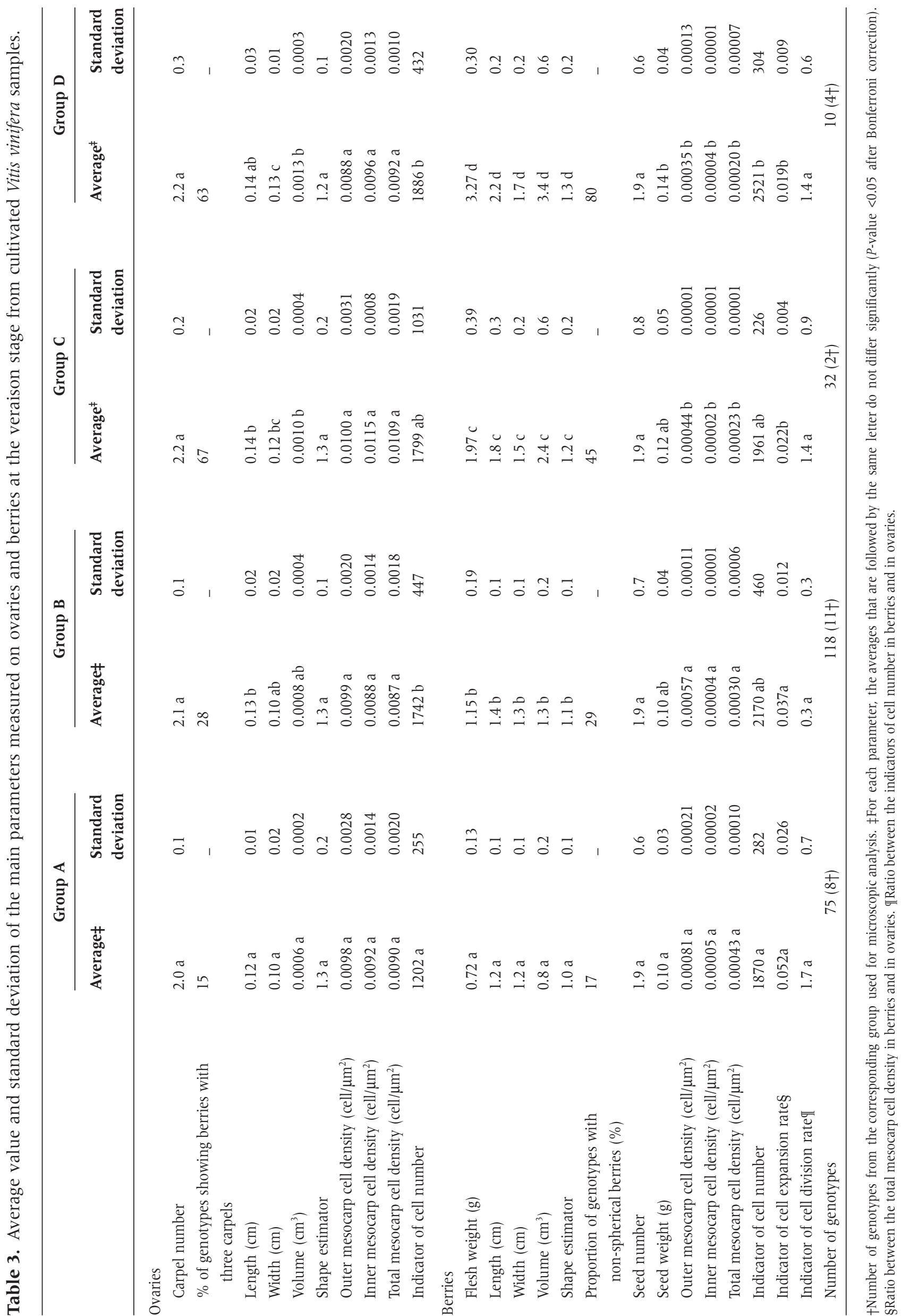




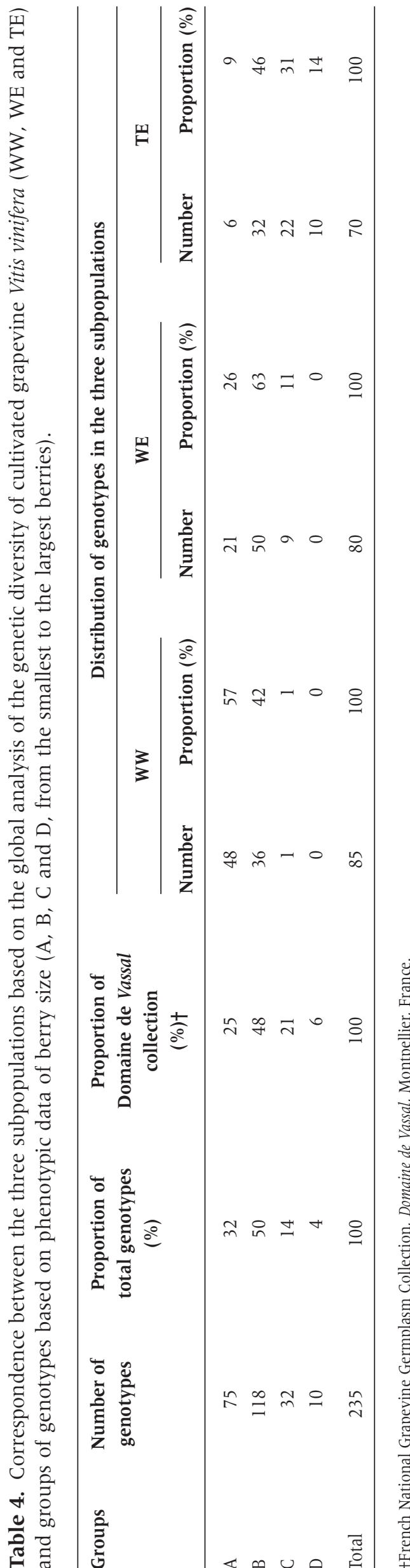

to be the factor explaining the variation in berry size between Groups A and B. The cell volume in berries at veraison was clearly the factor that differentiated Groups A and B from Groups C and D. In Group C, the number of cells in both ovaries and berries remained variable whereas it was significantly higher in Group D than in Group A. Finally, Group D, which contained the genotypes with the biggest berries, had the largest ovaries at anthesis, containing many large cells, resulting in large berries with many large cells.

\section{Discussion}

The correlation between berry weight at veraison and at ripeness in a large collection of diverse grapevine genotypes, observed in this study, indicated that the main determinants of the genetic variation for berry size occurs before veraison, that is to say during a stage of intense cell division associated with cell extension in the grapevine fruit (Ojeda et al. 1999). This suggests that early mechanisms such as cell division would be a major contributor of berry size variation between species.

Indicators of the cell number and size in ovaries and berries were then produced from histological observations in 26 genotypes. Although the sampling was carefully made to be representative of the genetic variabity of the whole sample, this number of genotypes was a little low for a study of the genetic variation of a trait, and the $\mathrm{C}$ and $\mathrm{D}$ Groups appeared to be under-represented. With this sampling, cell division before anthesis and cell expansion after anthesis were found to be likely involved in flesh weight variation between cultivars in the grapevine. Indeed, Coombe (1973) showed in the grapevine that 17 doublings of cell number occurred in the ovaries before anthesis compared with only two doublings after anthesis, which suggested that cell number in mature fruit was mainly determined before anthesis. In contrast, cell expansion increased fruit size by 300 -fold or more after anthesis (Coombe 1976) and was the greatest contribution to the total expansion of the fruit from anthesis to ripeness. This is in agreement with the present results showing that cell volume was stable between cultivars at anthesis but showed variation at veraison where it was correlated with final fruit size. The increase of berry volume via flesh cell expansion was shown to be influenced by cell wall plasticity and the accumulation of water and sugars (Coombe 1976), which is in turn influenced certainly by the number of vascular bundles. Interestingly, some preliminary results indicated that ovaries from Group D would present more vascular bundles than the ovaries from Group A (data not shown). Ovarian cell number and ovary vascular bundle number were already shown to be involved in sorghum kernel size variation by Yang et al. (2009), and Jackson and Coombe (1966) also demonstrated that cell number and volume at anthesis were the most important factors contributing to fruit size variation in apricot. In the tomato fruit and olive, the role of cell number in fruit variation was also demonstrated to occur at anthesis or before anthesis, increasing the range of fruit variation in combination with other traits, such as berry cell size and carpel number (Bertin et al. 2003, Cheniclet et al. 2005, Baldet et al. 2006, Cong et al. 2008, Rosati et al. 2011). A recent study on pumpkin plants (Nakata et al. 2012) which produced fruits weighing from one to several hundred kilograms found also that both the cell number and cell size were increased in a large fruit. These results suggest the importance of the combination of both mechanisms to increase significantly the size of the fruit between cultivars and are in agreement with our findings.

Each of these components may in turn be influenced by growth regulators (Coombe 1976, Ollat et al. 2002, Dauelsberg et al. 2011, Nitscha et al. 2012). In the present study, a positive 

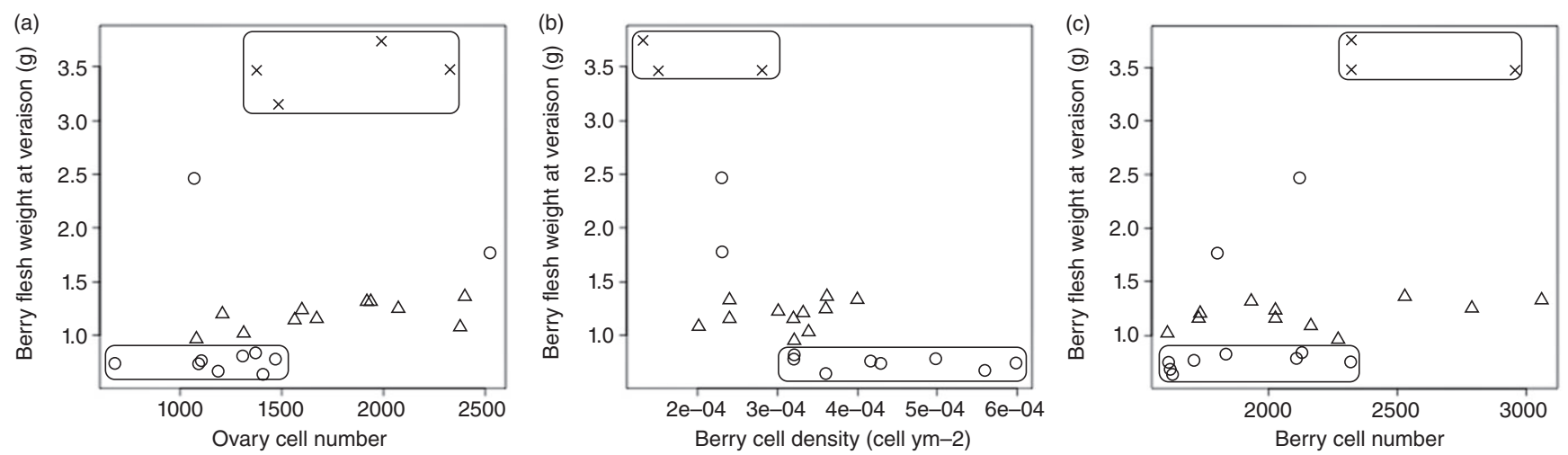

Figure 5. Correlation between berry flesh weight at veraison and (a) ovary cell number, (b) berry cell density and (c) berry cell number, on a sample of 26 genotypes from the four Groups: Group A (O), Group B $(\Delta)$ : Group C (+) and Group D (x). The berry cell volume is calculated from the berry cell density (see Materials and Methods).

correlation was found between the seed number and weight and the berry weight at the intragenotypic level, which was in agreement with previous results (Coombe 1960, Ollat et al. 2002, Dai et al. 2009a). The seed effect on berry growth was mainly related to growth regulator supply (Coombe 1973). Ojeda et al. (1999) suggested that seed growth might have a positive effect on cell mitosis in berry flesh development. Dai et al. (2009a) showed that the seed number affects berry growth especially during the first growth phase during which cell division occurs, and Dauelsberg et al. (2011) found that genes, involved into the synthesis of auxins, cytokinins and gibberelins, are upregulated shortly after fertilisation in grapevine ovaries. In tomato and apple, auxins produced by the seeds and/or surrounding fruit tissues are also known to trigger or accelerate fruit growth by cell expansion (Gillaspy et al. 1993, Lemaire-Chamley et al. 2005, Devoghalaere et al. 2012). The seed content could therefore influence berry size through hormonal mechanisms, more seeds or larger seeds producing more hormones than fewer or smaller ones. Another hypothesis would be that in large berries, seeds would find a less limited space to grow. However, although the genotypes with the largest berries always had the highest seed weight, the absence of an overall correlation between seed number or seed weight and berry flesh weight at the intergenotypic level in the cultivated grapevine suggested that this mechanism is unlikely to account for much of the variation in berry size. The observed threshold effect would have to be tested with a larger sample of genotypes carrying large berries.

Although fruit size in the cultivated tomato can vary by a factor of 200-fold (Tanksley 2004, Cheniclet et al. 2005), only a ten-fold variation was observed in the highly diverse set of 254 cultivated grapevine accessions phenotyped in the present work. This difference could be explained in part by the number of carpels that is highly variable in the tomato and has been demonstrated to have a strong influence in the variation of tomato fruit weight (Cong et al. 2008). This factor was proposed to be under selection pressure after the increase of ovarian cell number during the history of breeding for fruit size in tomato (Tanksley 2004). In the grapevine, this trait was shown in the present study to be much less variable than in tomato, as it varied between two and three carpels per ovary compared with two to more than 20 in the tomato (Cheniclet et al. 2005). Although this trait, however, does not seem to contribute to the overall berry size variation, cultivars from Groups C and D, which produced the largest berries, contained more genotypes with three carpels than Groups A and B.
The present study also suggested that, as in the tomato (Tanksley 2004), the increase of berry weight in the grapevine is correlated with the increase of berry shape diversity. This could be due either to loci having pleiotropic effects on fruit shape and fruit size or to parallel but independent selections for both traits in order to satisfy consumer demands. Indeed, the wild grapevine and tomato fruits are invariably round and small (Tanksley 2004, This et al. 2006) whereas cultivated fruits have a large range of size and shape. In favour of the first hypothesis, several genes involved in fruit size variation have a pleiotropic effect on fruit shape in the tomato (see for instance FASCIATED and the tomato WUSCHEL homolg gene which control the carpel number; Tanksley 2004). Moreover, the timing of division in different parts of the flesh, but also the direction of divisions (periclinal, anticlinal or random), and the interaction of both with the timing of cell expansion influence the final fruit shape (Coombe 1976, Wu et al. 2011) and could explain the correlation between fruit size and shape diversity, as for tomato. Indeed, the SUN locus controls tomato shape through the increase of cell division in the longitudinal direction and the decrease of cell division in the transverse direction of the fruit (Wu et al. 2011). The fact that the final berry shape was not predictable at the ovary stage may be due either to the accuracy of the method of measurement or that this trait is determined after fertilisation.

None of the variation in the measured traits could be superimposed with the evolutionary history that led to the genetic structure of the grapevine-cultivated gene pool in the three subpopulations WW, WE and TE. It was finally the clustering of genotypes into four groups (A, B, C, D) based on berry size traits (berry weight, length and width) that revealed the important mechanisms involved in berry size variation in the cultivated grapevine. The transition of berry size between the four groups of cultivars could be explained by a progressive selection of main traits: the berry cell number determined by the cell number in the ovaries, the intensity of cell division after anthesis and berry cell extension after anthesis. A natural mutant of $V$ vinifera cv. Ugni Blanc, which produces fleshless berries (Fernandez et al. 2006b), showed also fewer and smaller flesh cells than those from the Ugni Blanc wild-type (Fernandez et al. 2006a), indicating that the mutation in one locus is enough to explain such a transition. The most likely evolutionary scenario that would fit to these observations is that humans gradually selected mutations associated with an increase in fruit size, progressively leading to the present day cultivars which display a large range of size. Such a scenario has already been 
mentioned for tomato fruit history (MacArthur and Butler 1938, Banerjee and Kalloo 1989).

Berry size is also influenced by factors, such as berry location within the bunch, the number of berries per bunch and the plant source/skin ratio (Ollat et al. 2002, Dai et al. 2009b). In this preliminary study, the influence of the two first parameters on berry size variation was taken into account by randomly sampling berries only within several bunches from several plants. It will be important in future studies to design specific experiments for a better estimation of the interaction between genetic and environmental factors involved in berry size variation. In this study, however, there was a strong correlation between the average berry weight at veraison of 18 control genotypes measured in two successive years and at ripeness and with older data from the Domaine de Vassal database, which confirms earlier studies on the same traits (Singh and Jalikop 1986, Firoozabady and Olmo 1987). This study identified the veraison stage as the most interesting for the study of the berry size variation, as the berry size at veraison and ripeness are highly correlated while sampling at veraison is much more reliable than at ripeness. Indeed, the transition stage between ripeness and overripeness, where berry size can start to decrease (McCarthy 1999), is difficult to detect visually, especially for such a large collection of diverse genotypes.

\section{Conclusion}

This work identified the main anatomical factors (cell number and volume) and stages involved in berry size variation in $V$. vinifera that should guide future studies aiming at identifying the genetic determinism underlying this trait. It should also help the transfer of knowledge between the model fruit species for fleshy fruit development, the tomato and the grapevine.

\section{Acknowledgements}

This work was supported by the French Ministry of Research, the French Institute for Agronomical Research (INRA) and the ANR08-KBBE grant GrapeReSeq. We warmly thank Mireille Dessup and all the team of the INRA Domaine de Vassal (Marseillan-Plage, France) for technical assistance; Jacques Escoute, Marc Lartaud, Jean-Luc Verdeil and Fabienne Montes (Histology and Plant Cell Imaging Platform, CIRAD, Montpellier, France; http://phiv.cirad. fr/) for helping with the microscopic analysis; Cécile Guichard (INRA, Evry, France) for home-made script for data analysis; and Amidou N'Diaye (INRA, Montpellier, France) for assistance during phenotyping campaigns.

\section{References}

Baldet, P., Hernould, M., Laporte, F., Mounet, F., Just, D., Mouras, A., Chevalier, C. and Rothan, C. (2006) The expression of cell proliferationrelated genes in early developing flowers is affected by fruit load reduction in tomato plants. Journal Experimental of Botany 57, 961-970.

Banerjee, M.K. and Kalloo, G. (1989) The inheritance of earliness and fruit weight in crosses between cultivated tomatoes and two species of Lycopersicon. Plant Breeding 102, 148-152.

Bertin, N., Borel, C., Brunel, B., Cheniclet, C. and Causse, M. (2003) Do genetic makeup and growth manipulation affect tomato fruit size by cell number, or cell size and DNA endoreduplication? Annals of Botany 92, 415-424.

Boursiquot, J.-M., Dessup, M. and Rennes, C. (1995) Distribution des principaux caractères phénologiques, agronomiques et technologiques chez Vitis vinifera L. Vitis 34, 31-35.

Cabezas, J.A., Cervera, M.T., Ruiz-Garcia, L., Carreno, J. and MartinezZapater, J.M. (2006) A genetic analysis of seed and berry weight in grapevine. Genome 49, 1572-1585.

Cheniclet, C., Rong, W.Y., Causse, M., Frangne, N., Bolling, L., Carde, J.P. and Renaudin, J.-P. (2005) Cell expansion and endoreduplication show a large genetic variability in pericarp and contribute strongly to tomato fruit growth. Plant Physiology 139, 1984-1994.
Cong, B., Lui, J. and Tanksley, S.D. (2002) Natural alleles at a tomato fruit size quantitative trait locus differ by heterochronic regulatory mutations. Proceedings of the National Academy of Sciences of the United States of America 99, 13606-13611.

Cong, B., Barrero, L.S. and Tanksley, S.D. (2008) Regulatory change in YABBY-like transcription factor led to evolution of extreme fruit size during tomato domestication. Nature Genetics 40, 800-804.

Coombe, B.G. (1960) Relationship of growth and development to changes in sugars, auxins, and gibberellins in fruit of seeded and seedless varieties of Vitis vinifera. Plant Physiology 35, 241-250.

Coombe, B.G. (1973) The regulation of set and development of the grape berry. Acta Horticulturae 34, 261-271.

Coombe, B.G. (1976) The development of fleshy fruits. Annual Review of Plant Physiology 27, 507-528.

Cordonnier, E. (1976) Qualité de la vendange et méthodologie de la sélection viticole. Progrès Agricole et Viticole 93, 760-762.

Dai, Z.W., Genard, M., Li, S.H. and Vivin, P. (2009a) Analyzing the functional association among seed traits, berry growth and chemical composition in Cabernet-Sauvignon berry (Vitis vinifera L.) using a mathematical growth function. Journal International des Sciences de la Vigne et du Vin 43, 35-44.

Dai, Z.W., Vivin, P., Robert, T., Milin, S., Li, S.H. and Genard, M. (2009b) Model-based analysis of sugar accumulation in response to source-sink ratio and water supply in grape (Vitis vinifera) berries. Functional Plant Biology 36, 527-540.

Dauelsberg, P., Matus, J.T., Poupin, M.J., Leiva-Ampuero, A., Godoy, F. Vega, A. and Patricio Arce-Johnson, P. (2011) Effect of pollination and fertilization on the expression of genes related to floral transition, hormone synthesis and berry development in grapevine. Journal of Plant Physiology 168, 1667-1674.

Devoghalaere, F., Thomas Doucen, T., Baptiste Guitton, B., Jeannette Keeling, J., Payne, W., Ling, T.J., Ross, J.J., Hallett, I.C., Gunaseelan, K., Dayatilake, G.A., Diak, R., Ken, C., Breen, K.C., Tustin, D.S., Costes, E., Chagné, D., Schaffer, R.J. and David, K.M. (2012) A genomics approach to understanding the role of auxin in apple (Malus $\mathrm{x}$ domestica) fruit size control. BMC Plant Biology 12, 7. doi:10.1186/1471-2229-12-7.

Doligez, A., Bouquet, A., Danglot, Y., Lahogue, F., Riaz, S., Meredith, C.P., Edwards, K.L. and This, P. (2002) Genetic mapping of grapevine (Vitis vinifera L.) applied to the detection of QTL for seedlessness and berry weight. Theoretical and Applied Genetics 105, 780-795.

Fanizza, G., Lamaj, F., Costantini, L., Chaabane, R. and Grando, M.S. (2005) QTL analysis for fruit yield components in table grapes (Vitis vinifera). Theoretical and Applied Genetics 111, 658-664.

Fernandez, L., Pradal, M., Lopez, G., Berud, F., Romieu, C. and Torregrosa, L. (2006a) Berry size variability in Vitis vinifera L. Vitis 45, 53-55.

Fernandez, L., Romieu, C., Moing, A., Bouquet, A., Maucourt, M., Thomas, M.R. and Torregrosa, L. (2006b) The grapevine fleshless berry mutation. A unique genotype to investigate differences between fleshy and non fleshy fruit. Plant Physiology 140, 537-547.

Firoozabady, E. and Olmo, H.P. (1987) Heritability and correlation studies of certain quantitative traits in table grapes, Vitis ssp. Vitis 26, 132-146.

Frary, A., Nesbit, T.T.C., Grandillo, S., Knaap, E., Cong, B., Liu, J., Meller, J. Elber, R., Alpert, K.B. and Tanksley, S.D. (2000) FW2.2: a quantitative trait-locus key to the evolution of tomato fruit size. Science $\mathbf{2 8 9}, 85-88$.

Gillaspy, G., Ben-David, H. and Gruissem, W. (1993) Fruits: a developmental perspective. The Plant Cell 5, 1439-1451.

Guo, M. and Simmons, C.R. (2011) Cell number counts - the fw2.2 and CNR genes and implications for controlling plant fruit and organ size. Plant Science 181, 1-7.

Houel, C., Bounon, R., Chaïb, J., Guichard, C., Peros, J.-P., N'Diaye, A. Dereeper, A., Canaguier, A., Lacombe, T., Bacilieri, R., Le Paslier, M.-C., Vernerey, M.-S., Coriton, O., Brunel, D., This, P., Torregrosa, L. and AdamBlondon, A.-F. (2010) High level of homozygosity and signatures of selection in the region of the fleshless berry locus in grapevine. BMC Plant Biology 10, 284.

Jackson, D.I. and Coombe, B.G. (1966) The growth of apricot fruit. I Morphological changes during development and the effects of various tree factors. Australian Journal of Agricultural Research 17, 465-477.

Knapp, S.J., Stroup, W.W. and Ross, V.M. (1985) Exact confidence intervals for heritability on a progeny mean basis. Crop Science 25, 192-194.

Lacombe, T., Boursiquot, J.M., Laucou, V., Di Vecchi-Staraz, M., Peros, J.P. and This, P. (2012) Large-scale parentage analysis in an extended set of grapevine cultivars (Vitis vinifera L.). Theoretical and Applied Genetics $\mathbf{1 2 6}$ $401-414$.

Laucou, V., Lacombe, T., Dechesne, F., Siret, R., Bruno, J.-P., Dessup, M., Dessup, T., Ortigosa, P., Parra, P., Roux, C., Santoni, S., Vares, D., Peros, J.-P., Boursiquot, J.-M. and This, P. (2011) High throughput analysis of grape genetic diversity as a tool for germplasm collection management. Theoretical and Applied Genetics 122, 1233-1245. 
Le Cunff, L., Fournier-Leve, L.A., Laucou, V., Vezzulli, S., Lacombe, T., Adam-Blondon, A.-F., Boursiquot, J.-M. and This, P. (2008) Construction of nested core collections to optimize the exploitation of natural diversity in Vitis vinifera L. subsp sativa. BMC Plant Biology 8, 31. doi:10.1186/ 1471-2229-8-31.

Lemaire-Chamley, M., Petit, J., Garcia, V., Just, D., Baldet, P., Germain, V., Fagard, M., Mouassite, M., Cheniclet, C. and Rothan, C. (2005) Changes in transcriptional profiles are associated with early fruit tissue specialization in tomato. Plant Physiology 139, 750-769.

Lorenz, D.H., Eichhorn, K.W., Blei-holder, H., Klose, R., Meier, H. and Weber, E. (1994) Phänologische Entwicklungsstadien der Weinrebe (Vitis vinifera L. ssp. vinifera). Wein-Wissenschaft 49, 66-70.

MacArthur, J.W. and Butler, L. (1938) Size inheritance and geometric growth processes in the tomato fruit. Genetics 23, 253-268.

McCarthy, M.G. (1999) Weight loss from ripening berries of Shiraz grapevines (Vitis vinifera L. cv Shiraz). Australian Journal of Agricultural Research 5, 10-16.

Mejia, N., Gebauer, M., Munoz, L., Hewstone, N., Munoz, C. and Hinrichsen, P. (2007) Identification of QTL for seedlessness, berry size, and ripening date in a seedless $x$ seedless table grape progeny. American Journal of Enology and Viticulture 58, 499-507.

Mejia, N., Soto, B., Guerrero, M., Casanueva, X., Miccona, M., Houel, C., Le Cunff, L., Boursiquot, J.M., Hinrichsen, P. and Adam-Blondon, A.-F. (2011) Molecular, genetic and transcriptional evidence for a role of VvAGL11 in stenospermocarpic seedlessness in grapevine. BMC Plant Biology 11, 57. doi: 10.1186/1471-2229-11-57.

Muños, S., Ranc, N., Botton, E., Bérard, A., Rolland, S., Duffé, P., Carretero,

Y., Le Paslier, M.-C., Delalande, C., Bouzayen, M., Brunel, D. and Causse, M. (2011) Increase in tomato locule number is controlled by two singlenucleotide polymorphisms located near WUSCHELl. Plant Physiology 156, 2244-2254.

Nakata, Y., Taniguchi, G., Takazaki, S., Oda-Ueda, N., Miyahara, K. and Ohshima, Y. (2012) Comparative analysis of cells and proteins of pumpkin plants for the control of fruit size. Journal of Bioscience and Bioengineering 114, 334-341.

Negrul, A.M. (1946) Origin and classification of cultured grape. In: The ampelography of the USSR, Vol. 1. Eds. A. Baranov, Y.F. Kai, M.A. Lazarevski, A.M. Negrul, T.V. Palibin and N.N. Prosmoserdov (Pischepromizdat: Moscow, Russia) pp. 159-216.

Nitscha, L., Kohlenb, W., Oplaata, C., Charnikhovab, T., Cristescuc, S., Michielia, P., Wolters-Artsa, M., Bouwmeesterb, H., Mariania, C. Vriezena, W.H. and Rieua, I. (2012) ABA-deficiency results in reduced plant and fruit size in tomato. Journal of Plant Physiology 169, 878-883. Ojeda, H., Deloire, A., Carbonneau, A., Ageorges, A. and Romieux, C. (1999) Berry development of grapevines: relations between the growth of berries and their DNA content indicate cell multiplication and enlargement. Vitis 38, 145-150.

Ollat, N., Diakou-Verdin, P., Carde, J.-P., Barrieu, F., Gaudillère, J.-P. and Moing, A. (2002) Grape berry development: a review. Journal International des Sciences de la Vigne et du Vin 36, 109-131. University of Montpellier II, France, 214 pp.

Pritchard, J.K., Stephens, M. and Donnelly, P. (2000) Inference of population structure using multilocus genotype data. Genetics 155, 945-959.

Purugganan, M.D. and Fuller, D.Q. (2009) The nature of selection during plant domestication. Nature 457, 843-848.

Rosati, A., Caporali, S., Hammami, S.B.M., Moreno-Alias, I., Paoletti, A. and Rapoport, H.F. (2011) Differences in ovary size among olive (Olea europaea L.) cultivars are mainly related to cell number, not to cell size. Scientia Horticulturae 130, 185-190.

Singh, R. and Jalikop, S.H. (1986) Studies on variability in grape. Indian Journal of Horticulture 34, 207-209.

Tanksley, S.D. (2004) The genetic, developmental, and molecular bases of fruit size and shape variation in tomato. The Plant Cell 16, 181-189.

This, P., Lacombe, T. and Thomas, M.R. (2006) Historical origins and genetic diversity of wine grapes. Trends Genetics 22, 511-519.
Wu, S., Xiao, H., Cabrera, A., Meulia, T. and van der Knaap, E. (2011) SUN regulates vegetative and reproductive organ shape by changing cell division Ipatterns. Plant Physiology 157, 1175-1186.

Yang, Z., Oosterom, E.J., Jordan, D.R. and Hammer, G.L. (2009) Pre-anthesis ovary development determines genotypic differences in potential kernel weight in sorghum. Journal Experimental of Botany 60, 1399-1408.

Manuscript received: 11 July 2012

Revised manuscript received: 8 January 2013

Accepted: 1 February 2013

\section{Supporting information}

Additional Supporting Information may be found in the online version of this article at the publisher's web site: http:// onlinelibrary.wiley.com/doi/10.1111/ajgw.12021/abstract

Figure S1. Principal coordinate analysis of grapevine-cultivated accessions belonging at more than $80 \%$ to a given subpopulation based on a dissimilarity matrix obtained with 20 short sequence repeats (SSR). The accession from western wine, eastern wine and easter table subpopulation identified using STRUCTURE software are, respectively, represented by black, blue and green dots.

Figure S2. A. Correlation between the average berry flesh weight at ripeness collected in 2008 in our study and that present in the database of the French National Grapevine Germplasm Collection. B. Correlation between the average berry flesh weight at veraison collected in 2008 and 2009 in our study. (A) Plot of the average berry flesh weight at ripeness collected in 2008 and available in the database of the French National Grapevine Germplasm Collection. (B) Plot of the average berry flesh weight at veraison collected in 2008 and 2009.

Table S1. Plant material. Name of the cultivars, accession number, subpopulation and bunch Group belonging and year(s) of phenotyping of the sample used in this study. The genetic structure in three subpopulations was based on microsatellite genotyping (WW: wine grapes from Western Europe, WE: wine grapes from Eastern Europe and TE: table grapes from Eastern Europe; Laucou et al. 2011). The clustering into four Groups (A, B, C, D) was based on phenotypic data (berry flesh weight, berry length and berry width at veraison stage).

Table S2. Intragenotypic average and standard deviation for the parameters measured on three to ten ovaries or berries in 26 genotypes.

Table S3. ANOVA test of the difference in berry weight, seed weight, berry cell density and ovary cell density between the four Groups of genotypes, taking into account the intragenotypic variation. Table cells are in grey when the $P$-value is $<0.05$ after the Bonferroni correction. 